\begin{tabular}{|c|c|c|}
\hline Beitr. Ent. & Berlin & ISSN 0005-805X \\
\hline $\mathbf{5 0}(2000) 2$ & S. $397-405$ & 2000 \\
\hline
\end{tabular}

\title{
Contributions to the Lepidoptera fauna of the Madeiran Islands
}

\section{Introduction}

With 4 figures

\section{OLE KARSHOLT}

\section{Summary}

The present paper deals with the Madeiran Islands from a lepidopterological point of view. Short chapters summarize information on geography, geology, climate, and vegetation. The history of lepidopterological research in Madeira is presented, with references to additional literature. The origin of the approximately 300 species of Lepidoptera known from Madeira is briefly discussed, as are the problems with mislabeled material.

\section{Zusammenfassung}

Vorliegender Beitrag befaßt sich mit dem Madeira-Archipel aus lepidopterologischer Sicht. Kurze Kapitel fassen die Informationen zur Geografie, Geologie, Klima und Vegetation zusammen. Die Geschichte der lepidopterologischen Forschung auf Madeira wird vorgestellt, mit Hinweisen auf zusätzliche Literatur. Die Herkunft der etwa 300 bisher von Madeira bekannten Lepidopteren wird kurz diskutiert, wie auch die Probleme des fehletikettierten Materials.

\section{Key words}

Madeira; Lepidoptera; lepidopterists; laurisilva.

\section{Introduction}

The study of the fauna and flora of oceanic islands has always fascinated naturalists. It has provided a subject for speculation about how the organisms occurring there arrived at the islands, or if they originated there; it has also led to careful comparisons with taxa from the nearby continents. By this, such studies have contributed a lot to general understanding of zoogeography and speciation. This contribution is the first in a series of papers on the Lepidoptera of the Madeiran Islands.

\section{Geography and geology}

The Madeiran Archipelago is situated in the Atlantic Ocean between $32^{\circ} 20^{\prime}-33^{\circ} 10^{\prime} \mathrm{N}$ and $16^{\circ} 20^{\prime}-17^{\circ} 20^{\prime} \mathrm{W}$. The distance to Lisbon is $978 \mathrm{~km}$ and to the west coast of Morocco $630 \mathrm{~km}$. It lies between the Canary Islands (distance $380 \mathrm{~km}$ ) and the Azores (distance about $800 \mathrm{~km}$ ). The Selvages Islands are a group of islets situated $300 \mathrm{~km}$ south of Madeira. Administratively they form a part of Madeira, but they have strong biogeographic links with the Canary Islands. 
Together with the Azores, the Canary Islands and the Cape Verde Islands, Madeira forms the biogeographical region Macaronesia.

The Maderian Islands are composed of the main island Madeira $\left(728 \mathrm{~km}^{2}\right)$, Porto Santo, $57 \mathrm{~km}$ north-east of Madeira $\left(69 \mathrm{~km}^{2}\right)$, and the Desertas, three small islands $24 \mathrm{~km}$ south-east of Madeira (Chao, Deserta Grande, Bugio, altogether $15 \mathrm{~km}^{2}$ ). The highest elevation on Madeira is reached at Pico Ruivo (1862 m), Pico do Facho in Porto Santo (fig. 3) reaches $517 \mathrm{~m}$, and the highest elevation on the Desertas reaches $478 \mathrm{~m}$. On the main island of Madeira about one third of the area lies above $1000 \mathrm{~m}$.

The archipelago of Madeira is of volcanic orign, rising from depths of more than $4000 \mathrm{~m}$; it was never connected with any continent. There are considerable divergences in the estimats of the age of the Madeiran Islands, some ranging 60-70 million years back (SANTOS, 1990; PRESS $\&$ SHORT, 1994). However, there seems to be some consensus that Porto Santo has been subaerial for 12-13 million years, whereas Madeira has only been subaerial for 2-3 million years (SCHMINCKE, 1982; MITCHELL-THOMÉ, 1985; FAIRBRIDGE et al., 1997).

\section{Climate}

The climate is of Mediterranean type, rather homogeneous, but varies depending on the elevation and exposure. Trade winds, blowing from north and north-west play an essential role due to their influence on precipitation and relative humidity, setting fogs and rain especially on the northern slopes. The average annual precipitation varies much depending on the altitude: at Funchal at the south coast (25 m) it is $645 \mathrm{~mm}$, at Encumeada in central Madeira $(960 \mathrm{~m}) 2675 \mathrm{~mm}$, and at Porto Santo $(45 \mathrm{~m}) 338 \mathrm{~mm}$. The extreme eastern part of Madeira (Ponta de Sao Lourenco), Porto Santo, and the Desertas are semi-arid as they lie in the rain shadow of the Madeiran mountain range. Mean monthly temperatures range from around 15$20^{\circ} \mathrm{C}$ at Funchal to around $6-10^{\circ} \mathrm{C}$ at Bica da Cana. Dry and hot eastern winds from Africa are short-lived and relatively rare. Snow occasionally falls on the high peaks during winter months, but frost is rare (PRESS \& SHORT, 1994).

\section{Vegetation}

When Portuguese sailors discovered the islands of Porto Santo and Madeira in 1418 and 1419, respectively, they were impressed by the abundance of wild forest on the major island and named it 'Madeira', the Portuguese word for wood. A few years later settlers started to burn off the forest in order to grow crops. It is told that 'the island burned for 100 years', but this should probably be understood in the way that burning smaller areas for cultivation continued that long. However, the forest of the humid northern slopes of Madeira never became consumed by fire.

The most peculiar vegetation in Madeira is the evergreen laurel forest, called the laurisilva. It is considered a relict of the Tertiary subtropical forests which surrounded the Tethys Sea in what is now southern Europe and north-western Africa during Miocene and Pliocene (PRESS \& SHORT, 1994). Today, the Madeiran laurel forest covers about $10 \%$ of the island and is limited to the northern slopes of the island (figs 1-2). SANTOS (1990: 48) published a map of the present distribution of the laurisilva in Madeira. The vegetation on most of the southern part of the island, as well as along parts of the northern coast and into the valleys, is marked by human activity (these parts of Madeira are like a big garden), and the vegetation is secondary, with many introduced plants and trees. Because of this gardening the Madeirans take great care of the water, and a vast system of man-made aqueducts (levadas) bring the rain, which falls in the highland, down to lower elevations where it is used for irrigation. 

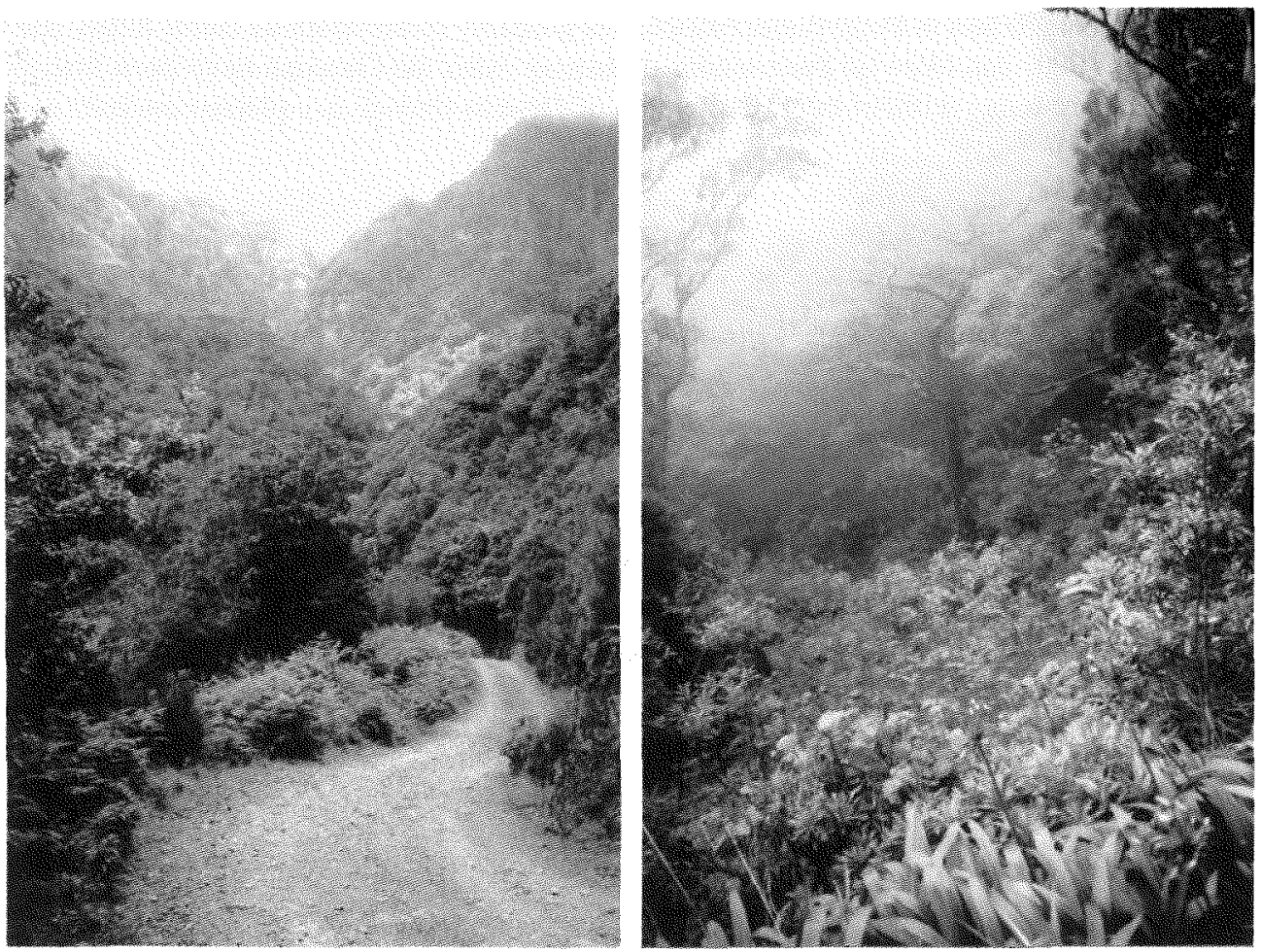

Fig. 1-2. Madeira. Interior part with laurisilva vegetation, about $1000 \mathrm{~m}$.

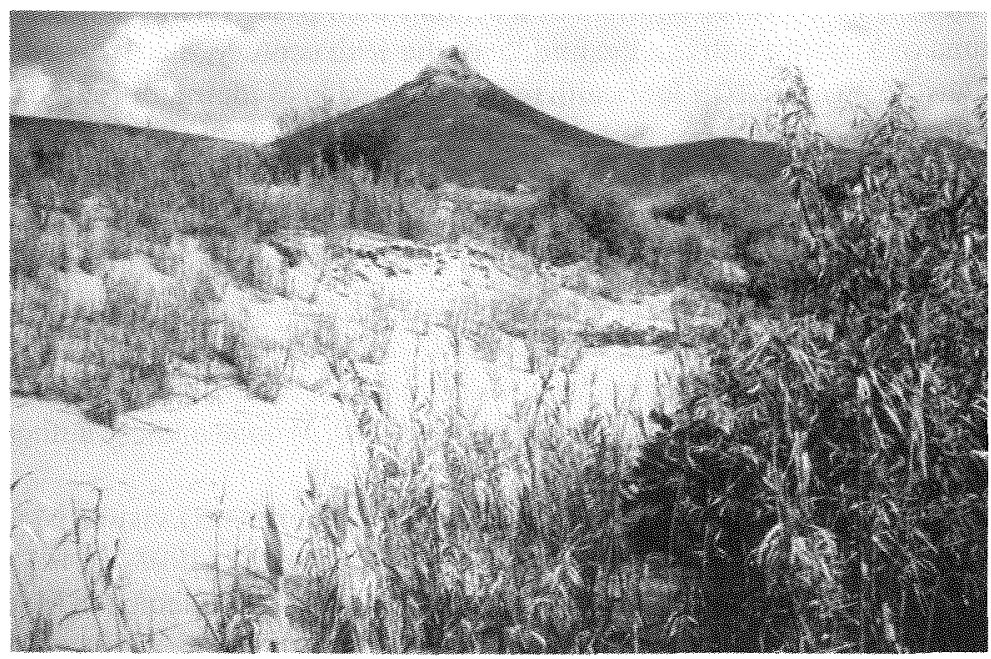

Fig. 3. Porto Santo. Pico do Facho seen from the southern coast.

In order to protect both gardens and forests, domestic animals are (now) kept away from the lower altitudes, but above $1000 \mathrm{~m}$ goats and sheep are numerous, and in certain parts of the highland (e.g., at Paul de Serra) the vegetation is destroyed. 
The natural vegetation in Porto Santo (which was probably thermophilous laurel forest, see SANTOS, 1990) has likewise been totally destroyed. Also the Desertas have been heavily grazed and are today without trees. On the top of Deserta Grande is a plateau covered with lichens (fig. 4).

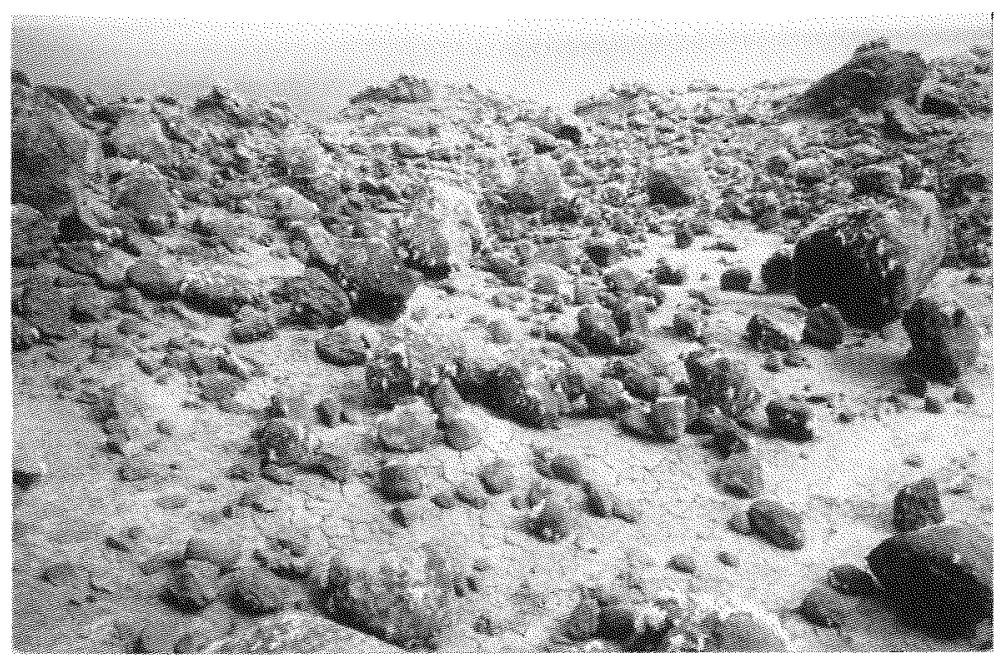

Fig. 4. Deserta Grande. Lichen-covered plateau, about $350 \mathrm{~m}$.

\section{History of lepidopterological research in Madeira}

The first species of Lepidoptera described from Madeira was the endemic satyrin, Papilio xiphia FABRICIUS, 1775. Three quarters of a century then passed without news on the lepidopteran fauna of Madeira until, in the middle of the 19th century, the British entomologist THOMAS VERNON WOLLASTON for health reasons stayed in Madeira for four longer periods between 1847 and 1855 (WOLLASTON, 1865; SALMON \& WALKEHAM-DAWSON, 1999). He collected in numerous localities in Madeira (though most of his specimens are only labeled 'Madeira'), and he visited also Porto Santo and the Deserta Islands. WOLLASTON's main interest was the beetles, and he published an impressive monograph of the Madeiran Coleoptera (WOLLASTON, 1854), but he also collected Lepidoptera, some of which he described himself (WOLLASTON, 1858). His material was furthermore the source for publications with descriptions of new species from Madeira by STAINTON (1859), BUTLER (1886), BETHUNE-BAKER $(1891,1894)$ and WALSINGHAM $(1894)$, as none of these authors collected there.

Around 1900 some British entomologists (e.g., EATON and LEECH) visited Madeira. Parts of their material were included in the works of WALSINGHAM $(1908,1910)$ (mainly on Canarian Microlepidoptera), but still very few Lepidoptera were collected in Madeira at that time, and only the collections of COCKERELL (1923) are of note.

During nearly half a century the famous Austrian lepidopterist HANS REBEL studied the lepidopteran fauna of the Canary Islands. In his publications (REBEL, 1892-1938) he also dealt with the fauna of Madeira, but it was only his latest publications (REBEL, 1940a-c) which were especially devoted to the fauna of these islands. They were based on material collected by LUNDBLAD and STORA. 
Before the Second World War one could reach Madeira only by ship, but the construction of airports first in Porto Santo and later in Madeira made access to the islands much easier. In the 1950s British lepidopterists such as ERIC W. CLASSEY, RAYMOND W. UFFEN and others visited Madeira and collected Lepidoptera there. Results from these collecting trips were published by e.g., by Bradley (1958), Gardner \& Classey (1960) and Karsholt \& SATTler (1998). The interest among Austrian lepidopterists in the moth fauna of the Macaronesian Islands continued during the second half of the last century. RUDOLF PINKER of Vienna visited Madeira five times in the late 1960s (PINKER, 1971). He collected mainly larger moths, using UV-light and searched for larvae. Pinker also brought back many Microlepidoptera, which were given to specialists like AMSEL and KLIMESCH. Other Austrian lepidopterists like GERFRIED DESCHKA (1976) and ERNST ARENBERGER devoted their main efforts in Madeira to the Microlepidoptera.

Between 1970 and 1977 the Danish lepidopterist NIELS L. WOLFF visited Madeira 12 times, partly assisted by other Danish entomologists. Wolff brought together what is probably the most comprehensive collection of Lepidoptera from Madeira. It was his intention to write a lepidopteran fauna of Madeira, and he made large efforts to clear up taxonomic problems, but he only managed to publish a few papers on this subject before his death (WOLFF, 1977a, b). A number of (especially larger) endemic moths in Madeira are very variable in wing markings, and the long series of fresh and well prepred specimens collected by WOLFF from different parts of the island give a good overview of this variation.

The collection of WOLFF is now in the Zoological Museum, University of Copenhagen, and this was a main reason why I felt a responsibility to continue research on the Lepidoptera of the Madeiran Islands. After a brief visit in February 1979 I visited Madeira for field work in June-July 1993, in October 1994, in April 1996 and in September 1997, altogether 13 weeks. Some results from these trips have been published (Nuss et al., 1998), while others are in preparation.

A number of other European lepidopterists have, during recent years, studied the Lepidopteran fauna of Madeira, mostly only for short time. Among these, the field work carried out by MARC MEYER of Luxemburg has resulted in several publications (e.g., MEYER, 1993), and that of HANS HENDERICKX in some remarkable discoveries (HENDERICKX, 1997; GAEDIKE \& KARSHOLT, in press).

The scanty but interesting butterfly fauna of Madeira has attracted specialists on this group, and several surveys of the butterflies there have been published (see SALMON \& WALKEHAMDAWSON, 1999 for references). The ecology of Madeiran butterflies, and especially of the endemic Pararge xiphia (FABRICIUS) in relation to the newly established, closely related $P$. aegeria (LINNAEUS) has been the subject of several papers (e.g., SHREEVE \& SMITH, 1992). Even though Madeira is administratively a part of Portugal only few Portuguese have studied the Lepidoptera fauna there. However, the most recent list of the Microlepidoptera of the Madeiran Islands is that of JOSÉ PASSOS DE CARVALHo (1995), who often visited Madeira. Although printed already in 1995 it was not distributed until early 1997. The former year is here accepted as the year of publication as the paper does not include descriptions of new taxa. This paper consists of two parts. In the first part PASSOS DE CARVALHO records the species studied by him, with details on locality and collecting dates. The other part is a check list of the Microlepidoptera of Madeira. This list is based on a photocopied list compiled by J. BRADLEY, formerly of Commonwealth Institute of Entomology in London, and includes the species of Microlepidoptera known from Madeira by him and by the late N. L. WOLFF. Unfortunately this list gives no details about the material, on which the listed species are based. The list includes 
a number of species which were not recorded before from Madeira. Several of these can be traced back to the collections of WOLFF (in the ZMUC), but for others it has not been possible to trace the origin. In some cases species in this list published by PASSOS DE CARVALHO (op. cit.) are clearly based upon misidentifications, and there are even discrepancies between the two parts of PASSOS DE CARVALHO's paper.

The local inhabitants of Madeira have only paid little attention to the study of the lepidopteran fauna of their islands, with ANTONIO M. F. AGUIAR as the sole exception. His combination of being a professional of applied entomology and an amateur lepidopterist has resulted in several interesting discoveries, especially on the bionomy of Madeiran Lepidoptera (e.g., MARKIN et al., 1995). He is currently working on an updated checklist and bibliography of the Lepidoptera of the Madeiran Islands (AGUIAR \& KARSHOLT, in prep.).

\section{Diversity of the Lepidoptera fauna of Madeira}

Because of its isolated position in the Atlantic Ocean and its small size, the lepidopteran fauna of the Madeiran Islands is relatively poor, numbering only about 300 species. The exact number can not be given at the present stage, because some families are still in need of revision. Moreover even many recent publications suffer from misidentifications and other inaccuracies.

The fauna consists of six major groups:

1) Species endemic to Madeiran Islands. This group contains so far known about $15 \%$ of the fauna. There are moreover a number treated as endemic subspecies.

2) Species endemic to the Macaronesian Islands. Most of these occur in Madeira and / or Porto Santo + one ore more of the Canary Islands.

3) Species with a wider distribution range, but which have established themselves in Madeira without being introduced by man. Most of these species are distributed also in southwestern Europe.

4) Species originally introduced to Madeira by man, but now being naturalized there (it is often difficult to distinguish between groups 3 and 4).

5) Immigrants crossing the ocean. Some of these are able to establish populations in Madeira, at least for some time.

6) Accidentally introduced species, viz. species which are imported by trade but which can not establish populations in the Madeiran climate.

A growing part of the lepidopteran fauna of Madeira belongs to group 3, and these species may even threaten the already existing fauna as has probably been the case in the genus Pieris, where the endemic (sub)species of the 'Large White', $P$. brassicae wollastoni (BUTLER), disappeared a couple of years after the introduction of $P$. rapae (LINNAEUS) in 1974 (WOLFF, 1975). However, most of the endemic Lepidoptera in Madeira have their strongholds in the more or less inaccessible, laurisilva-covered mountains in northern Madeira, and the protection of these areas also protects its lepidopteran fauna.

The Lepidoptera fauna of Madeira is related to that of southwestern Europe, as is the case with the flora and fauna in general (SANTOS, 1990: 23). There are also strong similarities with the fauna of the Canary Islands, whereas only few species are endemic only to the Madeira Islands t the Azores (see also HACKER \& SCHMITZ, 1996: 215). A more detailed, theoretical account of the zoogeography of Madeira and the Azores, mainly based on studies of the butterfly genus Hipparchia, was published by BALLETTO et al. (1990). 


\section{Misidentifications}

A special problem which must be to considered in connection with faunistic works is mislabeling of specimens. In my work with the Lepidoptera fauna of Madeira I relatively often came accross apparently mislabeled specimens. Such cases are probably more easily detected because of the relatively poor, isolated fauna of Madeira, where species originating from elsewhere are more easily detected. Moreover, at least in the past, there was a tendency not to discriminate precisely between the single islands of Macaronesia. Some entomologists visiting several islands did not keep the material collected on the single islands separate. Others passed material to others, who mixed up the islands when labeling the material (see also NUSS et al., 1998: 545). Already WOLLASTON had noticed this problem. In the introduction to one of his works he wrote a chapter on the "Importance of accuracy", beginning with: "Before proceeding further, I may perhaps be permitted to call attention to the paramount importance, ..., of the most perfect truthfulness on the question of habitat" (WOLLASTON, 1865: xix).

\section{Acknowledgements}

The author is indebted to Prof. HOLGER H. DATHE, Director of the Deutsches Entomologisches Institut, Eberswalde im Zentrum für Agrarlandschafts- und Landnutzungsforschung, Germany and Editor-inChief of the „Beiträge zur Entomologie“ for offering that this series could be published in this journal. He is moreover indebted to Dr. ANTÓNIO M. F. AgUIAR, Camacha, Madeira and to Dr. MARC MEYER, Musée national d'Histoire naturelle, Luxenburg for information on Madeira and its Lepidoptera; to MatTHIAS Nuss, Museum für Naturkunde, Dresden, Germany for stimulating discussions and for comments on the manuscript; to Dr. E. SCHOU JENSEN, Geologisk Museum, University of Copenhagen for help with literature; and to Dr. REINHARD GAEDIKE, Deutsches Entomologisches Institut, Eberswalde im Zentrum für Agrarlandschafts- und Landnutzungsforschung, Germany for editorial help and for preparing the German summary. Special thanks are due to my colleagues, Prof. NIELS P. KRISTENSEN for his continous support, and to Ms MARY E. PETERSEN for linguistic correction.

My work on the Lepidoptera of Madeira project was supported by a grant from the CARLSBERG Foundation, Denmark.

\section{References}

Balletto, E.; Giacoma, C.; Palestrini, C.; Rolando, A.; SarÀ, M.; Barberis, A.; Salvidio, S.; MENSI, P. \& CASSULO, L. 1990: On some aspects of the biogeography of northern Macaronesia. - Atti dei convei Lincei, Roma 85: 167-199.

BETHUNE-BAKER, G. T. 1891: Notes on the Lepidoptera collected in Madeira by the late V. T. WollaSTON. - Trans. ent. Soc. London 1891: 197-221, pl. XII.

Bethune-BAKer, G. T. 1894: Descriptions of the Pyralidae, Crambidae and Phycitidae collected by the late V. T. WOLLASTON in Madeira. - Trans. ent. Soc. London 1894: 581-586.

BRADLEY, J. D. 1958: Pyrales and Microlepidoptera collected by Mr. E. W. ClASSEY in Madeira, 1957. Entomologist London 91 (1144): 192-197.

COCKERELL, T. D. A. 1923: The Lepidoptera of the Madeira Islands. - Entomologist London 56: 243 $274,286$.

DESCHKA, G. 1976: Lithocolletidae from Madeira. - Ent. Ber. Amst. 36: 90-96.

FABRICIUS, J. C. 1775: Systema Entomologicae. 832 pp. Flensburgi et Lipsiae.

FAIRBRidGe, R. W.; Mitchell-ThOMÉ \& MOOREs, E. M. 1997: Portugal: Madeira. Pp. 621-623. - In: E. L. MOORES \& R. H. FAIRBRIDGE (eds): Encyclopedia of European and Asian Regional Geology. London, Weinheim, New York, Tokyo, Melbourne \& Madras.

GAEDIKE, R. \& KARSHOLT, O. in press: Contributions to the Lepidoptera fauna of the Madeiran Islands. 2. Tineidae, Acrolepiidae, Epermeniidae. - Beitr. Ent. 51

GARDNER, A. E. \& Classey, E. W. 1960: Report on the insects collected by the E. W. Classey and A. E. GARDNER Expedition to Madeira in December 1957. - Proc. S. Lond. ent. nat. Hist. Soc. 1959: 184-206. 
HACKER, H. \& SCHMITZ, W. 1996: Fauna und Biogeographie der Noctuidae des makaronesischen Archipels. - Esperiana 4: 167-221, pl. L-O.

HENDERICKX, H. 1997: Stigmella aurella and Luffia lapidella f. ferchaultella, new species for the Azores (Lepidoptera: Nepticulidae, Psychidae). - Phegea 25: 21-23.

KARSHOLT, O. \& SATTLER, K. 1998: A new brachypterous Ephysteris MEYRICK from the island of Madeira (Lepidoptera: Gelechiidae). - Entomologist's Gaz. 49: 35-47.

MARKIN, G. P.; SILVA, L. \& AGUIAR, A. M. F. 1995: The insect fauna associated with the tree Myrica faya (Myricaceae) in the Macaronesia Islands and on Mainland Portugal. - Bolm Mus. munic. Funchal, Supl. 4: 411-420.

MEYER, M. 1993: Die Lepidopteren der Makaronesischen Region. III. Die Tagfalter des nördlichen Makaronesiens (Madeira, Azores) aus biogeographischer Sicht (Papilionoidea). - Atalanta 24: 121162: pls VI-XIII.

MitCHELL-Thomé, R. C. 1985: Radiometric studies in Macaronesia. - Bolm. Mus. Munic. Funchal 37: $52-85$.

NUSS, M.; KARSHOLT, O. \& MEYER, M. 1998: A taxonomic revision of the Scopariinae from the Macaronesian region (Lepidoptera: Pyraloidea: Crambidae). - Ent. scand. 28: 509-551.

PASSOS DE CARVALHO, J. 1995: Microlepidoptera of the Madeira and Selvagem Archipelagoes (Insecta, Lepidoptera). - Bolm Mus. munic. Funchal, Suppl. 4: 559-588.

PINKER, R. 1971: Neue und interesante Lepidopteren aus Madeira und den Azoren mit faunistische Hinweisen auf die Kanaren. - Z. Wien. ent. Ges. 54: 101-134, pls 12-14.

Press, J. R. \& ShoRT, M. J. (eds) 1994: Flora of Madeira. xvii + 574 pp. London.

REBEL, H. 1892: Beitrag zur Microlepidopterenfauna des canarischen Archipels. - Annln naturh. Mus. Wien 7: 241-284, pl. XVII.

REBEL, H. 1896: Dritter Beitrag zur Lepidopterenfauna der Canaren. - Annln naturh. Mus. Wien 11: 102147, pl. III.

REBEL, H. 1906: Fünfter Beitrag zur Lepidopterenfauna der Kanaren. - Annln naturh. Mus. Wien 14: $22-44$.

REBEL, H. 1911: Sechster Beitrag zur Lepidopterenfauna der Kanaren. - Annln naturh. Mus. Wien 24: 327-374, pl. XII.

REBEL, H. 1917: Siebenter Beitrag zur Lepidopterenfauna der Kanaren. - Annln naturh. Mus. Wien 31: $1-62$.

REBEL, H. 1938: Achter Beitrag zur Lepidopterenfauna der Kanaren. - Annln naturh. Mus. Wien 49: (43)-(68).

REBEL, H. 1940a: Die Arthropodenfauna von Madeira nach den Ergebnissen der Reise von Prof. Dr. O. LuNDBLAD Juli - August 1935. XXI. Lepidoptera: Microlepidoptera. - Ark. Zool. 32A (2): 1-26, tab. I-III.

REBEL, H. 1940b: Die Arthropodenfauna von Madeira nach den Ergebnissen der Reise von Prof. Dr. O. LuNDBLAD Juli - August 1935. XXIII. Übersicht der Lepidopterenfauna Madeiras. - Ark. Zool. 32A (5): $1-13$

REBEL, H. 1940c: Die Lepidopterenfauna des Azorischen Archipels. Mit 1. Anhang: Eine LepidopterenAusbeute von Madeira. - Commentat. biol. 8 (1): 1-59, pls I-II.

REBEL, H. \& RogenHOFER, A. 1894: Zur Lepidopterenfauna der Canaren. - Annln naturh. Mus. Wien, 9: 1-96, pl. I.

Salmon, M. A. \& Walkeham-Dawson, A. 1999: Thomas Vernon Wollaston and the Madeiran Butterfly Fauna - a re-appraisal. - Br. J. ent. nat. Hist. 12: 69-88.

SANTOS, A. 1990: Evergreen forests in the Macaronesian region. - Nature and Enviromental Series, Strasbourg 49: $1-78$.

SCHMINCKE, H.-U. 1982: Volcanic an Chemical Evolution of the Canary Islands. Pp. 274-305. In: U. v. Rad et al. (eds): Geology of the Northwest African Continent Margin. Berlin, Heidelberg \& New York.

SHREEVE, T. G. \& SMITH, A. G. 1992: The role of weather-related habitat use on the impact of the European Spreckeled Wood butterfly Pararge aegeria on the endemic Pararge xiphia on the island of Madeira. - Biol. J. Linn. Soc. 46: 59-75. 
STAINTON, H. T. 1859: Notes on Lepidoptera collected in Madeira by T. V. Wollaston Esq. with descriptions of some new species. - Ann. Mag. nat. Hist. London (3)3: 209 - 214.

WALSINGHAM, M. A. 1894: Microlepidoptera from Norfolk and Scotland: including an addition to the British list. - Entomologist's mon. Mag. 30: 50-52.

WalsinghaM, M. A. 1908: Microlepidopters of Tenerife. - Proc. zool. Soc. Lond. 1907: 911-1034.

WaLsinghaM, M. A. 1910: Madeiran Tineidae (Lepidoptera). - Entomologist's mon. Mag. 46: 257-259.

WOLFF, N. L. 1975: On the sudden mass occurence in 1974 of Pieris rapae L. (Lepidoptera, Pieridae) in Madeira. - Bolm Mus. munic. Funchal 29: 26-32.

WOLFF, N. L. 1977a: Description of Mythimna serradaguae n. sp. from Madeira (Lepidoptera: Noctuidae). - Ent. scand. 8: 37-41.

WOLFF, N. L. 1977b: Xenochlorodes magna n. sp. from Madeira (Lepidoptera: Geometridae). - Ent. scand. 8: $42-48$.

WOLLASTON, V. T. 1854: Insecta Maderensia. xliii +634 pp, 13 pls. London.

WOLLASTON, V. T. 1858: Brief diagnostic characterization of undescribed Madeiran insects. - Ann. Mag. nat. Hist. (3) 1: 113-125.

WOLlaston, V. T. 1865: Coleoptera Atlantidum. xlvii, $526+140$ pp, 1 map. London.

Author's address:

OLE KARSHOLT, Zoological Museum

University of Copenhagen, Universitetsparken 15

DK 2100 Copenhagen $\varnothing$, Danmark

e-mail: okarsholt@zmuc.ku.dk

\section{Besprechungen}

RoTH, L. \& KoRMANN, K.: Ölpflanzen - Pflanzenöle. Fette - Wachse - Fettsäuren. Botanik Inhaltsstoffe - Analytik. - Landsberg: ecomed, verlagsgesellschaft, 2000 - 226 S.: 99 Farbabb. - ISBN 3-609-68700-2. - 128.- DM

Pflanzliches Öl gehört seit der Antike neben Getreide und Fleisch zu den wichtigsten Nahrungsmitteln des Menschen. Öllampen waren bis ins 19. Jahrhundert die wichtigste Lichtquelle bei Nacht. Auch heute werden Pflanzenöle vielfältig verwendet: als Salatöl, in Salben und Medikamenten, bei der Seifen- und Farbenherstellung, in der Nahrungsmittel- und Viehfutterproduktion.

Das vorliegende Nachschlage- und Grundlagenwerk vermittelt umfassende Informationen über Ölpflanzen und ihre Öle, Fette, Wachse und Fettsäuren. Ein Schwerpunkt des Buches ist die reichhaltig bebilderte Darstellung von über 50 Ölpflanzen von A wie Aleurites-Arten bis Z wie Zea mays. Botanische Merkmale, ölhaltige Pflanzenteile sowie Anbau und Verwendung sind für jede Pflanze systematisch beschrieben. Weit verbreitete und allgemein bekannte Ölpflanzen wie Sojabohne, Sonnenblume, Kaffee oder Haselnuß, sind ebenso aufgeführt wie unbekanntere Pflanzen (z.B. die Ölmadie oder der Pferderettichbaum).

Ebenso ausführlich und systematisch werden die Öle, Fette und Wachse, ebenfalls von A - Z, behandelt. Der Leser erfährt alles über Herkunft und Gewinnung, Hauptbestandteile sowie deren Chemie, Eigenschaften und Analytik, physikalische Daten und Verwendung.

Abgerundet wird das Buch durch die Darstellung der geschichtlichen Entwicklung, der wirtschaftlichen Bedeutung, der technischen Verfahren der Ölgewinnung und der pharmazeutischen Anwendung.

Das Buch ist in erster Linie gedacht als Nachschlage- und Grundlagenwerk für Apotheker, Landwirte, Ökotrophologen, Nahrungsmittelhersteller, Lebensmittelchemiker, Pharmazeuten, aber auch der Laie, der sich für die wirtschaftliche und verbrauchsorientierte Seite der Ölpflanzen und ihrer Öle interessiert, erfährt viel Wissenswertes. 